P'teridines

iol. 10, 1999, pp. 119-124

\title{
Neopterin in Autoimmune Rheumatic Diseases
}

\author{
Eugeney L. Nassonov ${ }^{1}$, Mikhail Y. Samsonov ${ }^{1}$, Barbara Wirleitner ${ }^{2}$, Gernot P. Tilz ${ }^{3}$, Dietmar Fuchs ${ }^{2 *}$ \\ Department of Rheumatology, Moscow Medical Academy, Moscow, Russia \\ -Institute of Medical Chemistry and Biochemistry, University of Innsbruck, A-6020 Innsbruck, Austria, and \\ Department of Internal Medicine, University of Graz, A-8036 Graz, Austria
}

Received August 30, 1999)

\begin{abstract}
Neopterin concentrations in body fluids allow to monitor the activation status of the cellular (=Thl-type) immune system in an easy but also sensitive way. Autoimmune disease result from deterioration of almost al immune system compartments. Rheumatic disorders comprise an important group of diseases featuring several aspects of autoimmune disorders. Already several years ago increased neopterin concentrations were demonstrated in patients with rheumatoid arthritis and later on in patients with systemic lupus erythematosus. Neopterin concentrations were found to correlate with the activity of the diseases and to conveniently indicate effects of therapy. Similar data were obtained in patients with acute rheumatic fever, and more recently, the utility of neopterin determination was also demonstrated in patients with Wegeners granulomatosis and with polymyositis/dermatomyositis. In this article we intend to summarize the current knowledge about the usefulness of neopterin measurements in patients with rheumatic diseases.
\end{abstract}

Key words : Neopterin, Autoimmune disease, Rheumatic disease

\section{Introduction}

Systemic rheumatic diseases, such as sistemic lupus erythematosus (SLE), rheumatoid arthritis (RA), polymyositis/dermatomyositis (PM DM) and Wegeners granulomatosis (WG) are multifactorial auto-immune disorders characterized by a diversity of clinical features which are matched by the many functional defects identificd in cells of the immune system. Defects of cytokine secretion which originate in the imbalance within subpopulations of CD4+ T helper (Th) lymphocytes (Th1 and Th2 lymphocytes) seem to play a fundamental role in the immunopathogenesis of autoimmune rheumatic dis-

$\$$ Address for correspondence: Dr. Dietmar Fuchs, Institute for Medical Chemistry and Biochemistry, University of Innsbruck, Fritz Pregl Strasse 3, A-6020 Innsbruck, Austria. eases (1). Thl lymphocytes produce mainly interlcukin-(IL)-2, interferon-g (IFN- $\gamma$ ), and tumor necrosis factor- $\alpha$ (TNF- $\alpha$ ) are primarily responsible for cell mediated immunity, while Th2 lymphocytes produce mainly IL-4, IL-5, IL-13, and IL-10, and are an important component of humoral immune response, supporting the activation of immunoglobulin secreting cells (2). Recent data show different patterns of cytokine production (Thl and Th2) between patients with autoimmune rheumatic diseases. In particular, based on these differences, RA (3-6) and WG (7) are considered to be "Thl cytokine driven" diseases, whereas $\operatorname{SLE}(8,10)$ and PM/ DM (9) are considered to be "Th2-cytokine dependent" diseases. However, patterns of cytokines seem to be controversial in autoimmune rheumatic diseases. In fact, different clinical presentations of diseases are characterized by distinct cytokine secretion 
profiles. For example, the elevated serum concentrations of IFN- $\gamma$ and TNF- $\alpha$ (11), both Thl-type cytokines, were found in SLE patients with lympadenopathy, nephrotic syndrome and thrombocytopenia, respectively. Moreover, accurate evaluation of cytokine levels is very difficult due to their short serum half-life (12), rapid uptake/utilization in vivo (13) and/or the presence of blocking factors such as soluble receptors on inhibitors in serum. $(14,15)$. An alternative approach is to measure serum concentrations of biologically stable products of immune activation.

From a clinical point of view, neopterin is a particularly useful marker and increased production of neopterin is characterized by the synthesis of a certain pattern of cytokine in human disease states. Increased concentrations of neopterin in serum and urine have been observed in patients with a number of neoplastic, infectious, and immune mediated diseases (16), including autoimmune rheumatic diseases (17). Neopterin, a by-product of the guanosine triphosphate pathway, is produced by activated macrophages upon stimulation with IFN- $\gamma$ (Thltype of cytokine) (18). In other cells, only small production rates of neopterin could be demonstrated in vitro and it seems that they are of minor relevance as an additional source of increased neopterin concentrations in patients. TNF- $\alpha$ has been found to be a potent costimulus for the production of neopterin (19-21), and vice versa, exogenous neopterin increased TNF- $\alpha$ synthesis in human macrophages (22) and vascular smooth muscle cells (23). These findings arc particularly important since significant amounts of TNF- $\alpha$ have been documented in the tissue and blood of patients with autoimmune rheumatic diseases, c.g., RA. Serum concentrations of both types of sTNF-Rs correlate to some degree with levels of TNF- $\alpha$, and clevated serum levels of sTNF-55R and sTNF-75R also correlate with neopterin in patients with autoimmune rheumatic diseases.

Iis article our findings in patients with autoimmune rheumatic diseases are reviewed and extended.

\section{Pnts and Methods}

The general characteristics of patients with autoimmune rheumatic disease which are summarized in this study are shown in Table 1 . The diagnosis of SLE was based on the revised criteria of American Rheumatism Association (1982) (24). The Index of European Consensus Lupus Activity Measurement (ECLAM) was used for calculating disease activity (25).

Patients with RA met American College of Rheumatology criteria for classical RA (26). The relationship between clinical variables and serum neopterin levels was investigated. Disease activity and disease severity indices were determined as described by W. Wilkey, et al. for more accurately assessment (27). Disease activity index includes the following 4 parameters: pain (none $=$ score 0 , intermittent $=$ score 1 , constant $=$ score 2$)$, duration $(\min )$ of early morning stiffens $(<15=$ score $0,15-30$ $=$ score $1,>30=$ score 2 ), total count of swollen and/or tender joints $(0-2=$ score $0,3-5=$ score $1,>5$ $=$ score 3$) ; \operatorname{ESR}(\mathrm{mm} / \mathrm{h}):<30=$ score $0,30-45$ $=$ score $1,>35=$ score 2 ). Total maximum score is 8 . Severity disease index was computed by adding the prognostic factors to disease activity score. Prognostic factors include the following parameters: deteriorating functional capacity during previous 6 monthscore 1; sustained ( $>6$ month) clevated ESR $(>30$ $\mathrm{mm} / \mathrm{h}$ ) - score l; RF titer (>1:640 latex); extraarticular disease (rheumatoid nodules, inflammatory eye disease, sicca complex, vasculitis, and pleural or pulmonary disease - score 1. Total score is 5. Articular damage was assessed radiologically by modified Sharps method.

Patients with PM/DM fulfilled the definite criteria of Bohan and Peter (28) for PM and DM. Fifteen patients with primary PM, 13 patients with primary DM and 16 patients with myositis and systemic sclerosis in overlap were investigated. The global clinical assessment was based on a physical examination, measurement of muscle strength using the MRC scale (neuromuscular score) and activities of daily living questionnaire (ADL).

Patients with WG fulfilled the American College of Rheumatology criteria for WG (29). Among 26 patients, 17 were considered to have generalized WG and 9 were classified as having a limited form of disease. The Birmingham Vasculitis Activity Score (BVAS) was used to evaluate disease activity (30).

Table l. Characteristic of patients with autoimmune rheumatic discases

\begin{tabular}{|c|c|c|c|}
\hline & $\mathrm{Nr}$ of patients & Sex Female/malc & Age Mean(range) \\
\hline Systemic lupus crythematosus & 52 & $47 / 5$ & 31 \\
\hline Rheumatoid arthritis & 67 & $57 / 10$ & 45 \\
\hline Polymyositis/dermatomyositis & 44 & $33 / 11$ & 38 \\
\hline Wegener's granulomatosis & 26 & $15 / 11$ & 42.2 \\
\hline
\end{tabular}

Pteridines / Vol. $10 /$ No. 3 
Serum neopterin was measured by radioimmunoassay or ELISA (BRAHMS, Berlin, Germany). Concentrations of $55 \mathrm{kDa}$ sTNF-R and sIL-2R were also measured by commercially available ELISA. All tests were performed according to the manufacturers instructions. The upper normal limit of all immune markers was taken as the mean of an internal control group \pm 2 S.D.: neopterin $8.8 \mathrm{nmol} / 1$ $(5.2 \pm 1.8 \mathrm{nmol} / \mathrm{l}, \mathrm{n}=31)$; sTNF-55R $4.2 \mathrm{ng} / \mathrm{ml}$ $(2.55 \pm 0.78 \mathrm{ng} / \mathrm{ml}) ;$ sIL-2R $913 \mathrm{U} / \mathrm{ml}(509 \pm 202$ $\mathrm{U} / \mathrm{ml}$ ).

\section{Results}

As shown in Table 2, serum neopterin concentrations were found to be raised in $73 \%$ of patients with SLE, in $47 \%$ of patients with RA, in $80 \%$ of patients with $\mathrm{PM} / \mathrm{DM}$ and in $50 \%$ patients with WG. Mean values of neopterin in patients with autoimmune rheumatic diseases were significantly higher as compared with healthy volunteers ( $p$ $<0.0001$ in all cases). Mean values or frequency of neopterin elevations above normal did not signifi-

Table 2. Scrum concentrations of neopterin in patients with autoimmune rheumatic diseases and in normal controls (mean \pm S.D., percent with levels above the $95^{\text {th }}$ percentile of healthy controls)

\begin{tabular}{ll}
\hline \hline Disease & Neopterin $(\mathrm{nmol} / \mathrm{l})$ \\
\hline $\begin{array}{l}\text { Smic lupus erythematosus } \\
\text { hn=52 }\end{array}$ & $10.5 \pm 6.1973 \%)$ \\
Rheumatoid arthritis & $10.5 \pm 6.1(47 \%)$ \\
hn=55 & \\
$\begin{array}{l}\text { Polymyositis/dermatomy- } \\
\text { Ositis }\end{array}$ & $20.0 \pm 14.6(80 \%)$ \\
hn=44 & \\
$\begin{array}{l}\text { Wegener's granulomatosis } \\
\text { hn=27 }\end{array}$ & \\
Controls & $5.2 \pm 1.8\left(5^{\circ} \%\right.$ \\
hn=31 &
\end{tabular}

Table 3. Spcarman rank coefficients (rs) of correlation between serum neopterin concentrations and the main clinical and laboratory parameters in patients with rheumatoid arthritis

\begin{tabular}{lll}
\hline \hline & \multicolumn{1}{c}{ rs } & \multicolumn{1}{c}{$\mathrm{p}$} \\
\hline Ritchie articular index & 0.409 & 0.0001 \\
Lansbury articular index & 0.402 & 0.001 \\
Activity index & 0.374 & 0.002 \\
Severity index & 0.441 & 0.0001 \\
C-reactive protein & 0.335 & 0.02 \\
ESR & 0.458 & 0.0001 \\
\hline
\end{tabular}

cantly differ between groups of patients with different diseases.

In SLE a strong positive correlation between serum concentrations of neopterin and ECLAM score ( $\mathrm{rs}=0.59, \mathrm{p}<0.0001$ ) was established. The associations between other markers of immune activation and ECLAM score were significantly weaker as compared with neopterin (s $\mathrm{TNF}-55 \mathrm{R}$ : $\mathrm{rs}=0.30$, $\mathrm{p}=0.05$; sIL-2R: $r s=0.37, \mathrm{p}<0.05$ ).

In patients with RA the serum concentrations of neopterin significantly correlated with several clinical parameters of disease activity. (Table 3 ). The serum levels of neopterin in patients with highest activity (>6) and severity (>9) scores were significantly elevated as compared with patients with low activity $(<5)$ and low severity $(<5)$ scores (Table 4 ). During follow-up (12 month), significant decrease of serum neopterin was observed in patients with a $>20 \%$ improvement (Table 5) compared with patients without according to the ACR criteria (31).

In patients with $\mathrm{PM} / \mathrm{DM}$ the medium levels of neopterin were significantly higher in those with myositis overlap $(26.8 \pm 19.1 \mathrm{nmol} / \mathrm{l})$ and primary $\mathrm{DM}(20.6 \pm 11.3 \mathrm{nmol} / \mathrm{l})$ as compared with primary $\mathrm{PM}(11.3 \pm 4.6 \mathrm{nmol} / \mathrm{l}) \quad(\mathrm{p}=0.007$ and $\mathrm{p}=0.005$, respectively). There were no correlations between

Table 4. Scrum concentrations of neopterin acoording to discave ativity and veverity indices in patients with rheumatoid arthritis

\begin{tabular}{|c|c|c|c|}
\hline & & Activity index & \\
\hline & $<5, \mathrm{n}=28$ & $5-6, n=22$ & $>6, n=17$ \\
\hline \multirow[t]{4}{*}{ Neopterin (nmol/l) } & $9.2 \pm 4.5$ & $9.6 \pm 3.4$ & $14.0 \pm 8.9$ \\
\hline & $\begin{array}{c}<5 \text { versus }>6 \\
h p=0.022\end{array}$ & $\begin{array}{c}<5 \text { versus }>5-6 \\
p>0.05\end{array}$ & $\begin{array}{c}5-6 \text { versus }>6 \\
p>0.051\end{array}$ \\
\hline & & Sity index & \\
\hline & $<5, \mathrm{n}=17$ & $5-8, n=26$ & $>8, \mathrm{n}=24$ \\
\hline \multirow[t]{2}{*}{ Nerin (nmol/1) } & $7.8 \pm 2.0$ & $10.0 \pm 4.8$ & $13.1 \pm 7.9$ \\
\hline & $\begin{array}{c}<5 \text { versus }>8 \\
p=0.018\end{array}$ & $\begin{array}{c}<5 \text { versus } 5-8 \\
p>0.05\end{array}$ & $\begin{array}{c}5-8 \text { versus }>8 \\
p>0.05\end{array}$ \\
\hline
\end{tabular}


Table 5. Associations between changes of serum of neopterin concentrations and disease activity in patients with rheumatoid arthritis

\begin{tabular}{lcc}
\hline \hline & \multicolumn{2}{c}{ Neopterin $(\mathrm{nmol} / \mathrm{l})$} \\
\cline { 2 - 3 } & Bine & $\begin{array}{c}\text { After } 12 \\
\text { months }\end{array}$ \\
\hline$>20 \%$ improvement $(\mathrm{n}=23)$ & $11.3 \pm 7.7$ & $7.9 \pm 2.2^{*}$ \\
$<20 \%$ improvement $(\mathrm{n}=15)$ & $11.9 \pm 5.4$ & $11.7 \pm 4.8^{*}$ \\
\hline${ }^{*} \mathrm{p}=0.04$ & &
\end{tabular}

Table 6. Spearman rank coefficients ( $\mathrm{rs}$ ) of correlation between neopterin and sTN!F-55R and sIL-2R concentrations in patients with autoimmune rhcumatic diseases

\begin{tabular}{lcc}
\hline \hline & $s T N F-55 \mathrm{R}$ & sIL-2R \\
\hline Smic lupus crythematosus & 0.68 & 0.35 \\
& $\mathrm{p}<0.0001$ & $\mathrm{p}<0.01$ \\
Rhcumatoid arthritis & 0.32 & 0.26 \\
& $\mathrm{p}<0.01$ & $\mathrm{p}<0.06$ \\
Polymyositis/dermatomyositis & 0.46 & 0.70 \\
& $\mathrm{p}<0.001$ & $\mathrm{p}<0.0001$ \\
Wegencrs granulomatosis & 0.80 & 0.55 \\
& $\mathrm{p}<0.001$ & $\mathrm{p}<0.01$ \\
\hline
\end{tabular}

neopterin and neuromuscular score, ADL score and serum creatine kinase. Elevated serum concentrations of neopterin were found in a group of patients with pronounced muscle weakness and normal creatine kinase level. Interestingly, all these patients had severe non-muscular (systemic) manifestations, such as arthritis, Raynauds phenomenon and sclerodermalike features.

In patients with WG BVAS index and neopterin correlated strongly ( $\mathrm{rs}=0.59, \mathrm{p}<0.01)$. In 9 patients with active WG (BVAS $>10)$ mean neopterin was significantly higher as compared with 13 patients with inactive disease $(11.4 \pm 4.2 \mathrm{nmol} / \mathrm{l}$ versus $6.2 \pm$ $2.4 \mathrm{nmol} / 1, \mathrm{p}<0.05)$.

In all groups of patients with autoimmune rheumatic diseases serum neopterin concentrations correlated more or less strong with sTNF-55R and in some cases also with sIL-2R (Table 6). Moreover, our preliminary results indicate that serum concentrations of neopterin (but not sIL-2R and sTNF55R) weakly, but significantly correlate with serum concentrations of soluble intercellular adhesion molecules $3(n=34, r s=0.430, p=0.02), I L-13(n=41$, $\mathrm{rs}=0.359, \mathrm{p}=0.02)$ and von Willebrand factor antigen $(n=36, r s=0.376, p=0.02)$.

\section{Discussion}

Our studies confirm and extend the observations on increased serum concentrations of neopterin in the majority of patients with autoimmune rheu- matic diseases. Individual neopterin concentrations correlate with disease activity as well as with serum concentrations of sTNF-55R and sil-2R (32-34). Results from serial measurements of serum neopterin in RA appear to be especially important. it should be stressed that assessment of disease activity and progression of RA is still an unresolved clinical problem (35). One of the most important outcome measures in RA is radiological progression. A relationship between acute phase protein, especially Creactive protein (CRP), and disease activity and radiological evidence of joint damage has been demonstrated in several clinical studies. (36). We found a significant correlation between serum concentrations of neopterin and disease activity in RA patients. Similar observation concerning urinary or synovial fluid neopterin have been reported by other investigators (37). In addition, we showed that patients with persistently elevated neopterin concentrations tended to have higher radiological progression rates than patients with low neopterin levels over a one year of follow-up. Moreover, our preliminary results indicate that in a group of patients with RA there was a better correlation between radiological progression and neopterin concentrations than between radiological progression and CRP and ESR. To our knowledge, this is the first report of prognostic significance of neopterin in RA.

RA and WG are considered to be diseases driven by Thl-(IFN- $\gamma$ and TNF- $\alpha$ )-type cytokines and, in agreement, neopterin concentrations reflect activity and severity of these diseases. On the contrary, similar findings in patients with SLE and PM/DM seem paradoxical, because they are classified as Th2-type cytokine dependent diseases. However, there is also recent evidence that both, Th1-type and Th2-type, cytokines may be involved in their pathogenesis (38, 39 ). For instance, in murine lupus models, the IgG isotypes, $\operatorname{IgG} 2 \mathrm{a}, \operatorname{IgG} 2 \mathrm{~b}$ and $\operatorname{IgG} 3$, which are most relevant for pathogenesis, depend on IFN- $\gamma$. Nephritogenic antibodies in lupus are Thl cell dependent $(40,41)$. Treatment with anti-IFN- $\gamma$ antibodies (42) or soluble IFN- $\gamma$ receptors (43) delays disease onset and reduces mortality. IFN- $\gamma$ concentrations are increased during active SLE and decline after treatment (44). In MRL/lpr model, it was shown that IFN- $\gamma-/-$ knockout mice had less end-organ disease (45). Moreover, it has been recently demonstrated that decreased production of ThI-type cytokines can occur early in the course of SLE and is not a feature of well-established disease (46). A strong correlation between both neopterin and sTNF-55R concentrations with each other and with disease activity suggests that elevated neopterin concentra- 
Table 7. Value of serum neopterin measurement in the clinical assessment of autoimmunc rheumatic diseases

\begin{tabular}{|c|c|c|c|}
\hline Discase & $\begin{array}{l}\text { Activity } \\
\text { marker }\end{array}$ & $\begin{array}{c}\text { Response to } \\
\text { therapy }\end{array}$ & $\begin{array}{l}\text { Prognostic } \\
\text { index }\end{array}$ \\
\hline $\begin{array}{l}\text { Systemic lupus } \\
\text { erythematosus }\end{array}$ & + & $?$ & $?$ \\
\hline Rheumatoid arthritis & + & + & + \\
\hline $\begin{array}{l}\text { Polymyositis/ } \\
\text { dermatomyositis } \\
\text { etomyositis }\end{array}$ & + & $?$ & $?$ \\
\hline $\begin{array}{l}\text { Wegener's } \\
\text { granulomatosis }\end{array}$ & + & $?$ & $?$ \\
\hline
\end{tabular}

tions reflect the pathogenetic significance of the Thl-dependent immune system activation in SLE. From a clinical point of view it is important that serum concentrations of neopterin more closely correlate with clinical manifestations of SLE activity than other immune markers such as anti-DNA antibodies, sTNF-55R and sIL-2R.

Also in patients with $\mathrm{PM} / \mathrm{DM}$ highest concentrations of neopterin (and also sTNF-55R and sIL-2R) are associated with non-muscular overlapping involrement, which is characterized by more gencralized (Thl and Th2 type cytokine dependent) activation of the immune system. From a clinical point of view, the determination of neopterin might be especially useful for the evaluation of global discase activity: The clinical significance of neopterin determination in patients with autoimmunc rheumatic discases is summarized in Table 7 .

\section{References}

1. Romagnani S. TH1 and TH2 in hum.m discases. Clin Immunol Immunopathol 1996; 80: 225-235.

2. Mosman TR, Sad S. The expanding univere of 'l-cell subsets: Th1, Th2 and more. Immunol. Tod.x 1996; 17: $138-146$.

3. Shulze-Koops H, Lipsky PE, Kavanaugh AF Dais I.S. Elevated Thl- or Tho-like cytokine mRNA in peripheral circulation of patients with rhcumatoid arthritis. J Immunol 1995; 155: 5029-5037.

4. Miltenburg AJ, van Laar JM, de Kíuper R, et al. T eclls cloned from human rheumatoid svonovial membrane functionally the Thl subset. Scand J Immunol 1992; 35: $603-610$.

5. Quayle AJ, Chomarat P, Miossec P, et al. Rheumatoid inflammatory T-cell clones express mostly Thl but also Th2 and mixed (Th0-like) cvtokine patterns. Scand J Immunol 1993; 38: 75-82.

6. Feldman M, Brennan FM, Maini RN. Role of cytokines in rheumatoid arthritis. Annu Rev Immunol 1996; 14: 397-440.

7. Csernok E, Trabandt A, Muller A, et al. Cytokine profiles in Wegeners granulomatosis. Predominantly of
Type 1 (Thl) in the granulomatosis inflammation. Arthritis Rheum 1999; 42: 742-750.

8. Lauwerys BR, Houssiau FA. Cytokines: clues to the pathogenesis of SLE. Lupus 1998; 7: 211-213.

9. Caligaris-Cappio F, Bertero M, Converso M, et al. Circulating levels of soluble CD30, a marker of cells producing Th2-tipe crtokines, are increased in patients with srstemic lupus erythematosus and correlate with disease activity: Clin Exp Rheumatol 1995; 13: 339343.

10. Hagiwara E, Adams EM, Plotz PH, Klinman DM. Abnormal number of cytokine producing cells in patients with polymyositis and dermatomyositis. Clin Exp Rheumatol 1996; 14: 485-491.

11. Al-Janadi M, Al-Ball S, Al-Dalaan A, Raziuddin S. Citokine profile in systemic lupus erythematosus, rheumatoid arthritis and other rheumatic diseases. J Clin Immunol 1993; 13: 58-67.

12. Oliver JC, Bland LA, Oettinger CW. Arduino M., McAllister S.K. Cytokine kinetics in an in vivo whole blood model following an endotoxin challenge. Lymp Cytokine Res 1993; 12: 115-120.

13. Waager A, Brandtzacg P, Halstensen A, et al. The complex pattern of cytokine in serum from patients with meningococcal septic shock. J Exp Med 1989; 169: 333-338.

14. Engelberts I, Stephens S, Francot CJ, et al. Evidence for different effects of soluble TNF receptors on various TNF measurement in human biological fluids. Lancet 1991; 338: 515-516.

15. Bzen K, Svenson M, Jonsson V, Hippe E. Autoantibodics to crtokines -friends or foes? Immunol Today 1990; 5: 167-169.

16. Fuchs D, Hausen A, Reibnegger G, Werner ER, Dierich MP. Wachter H. Neopterin as a marker for activated cell-mediated immunity: application in HIV infection. Immunol Todav 1988; 9: 150-155.

17. Fuchs 1), Neopterin. A message from the immune system. 1998, BRAHMS Diagnostic GmbH.

18. Huber C, Batchelor JR, Fuchs D, et al. Immune response-associated production of neopterin. Release from macrophages primary under control of interferongammi. J Exp Med 1984; 160: 310-316.

19. Tmair J, Nachbauer $K$, Herold $M$, et al. In vitro and in vivo studies on the induction of neopterin synthesis by cytokines, alloantigens and lipopolysaccaride (LPS). Clin Exp Immunol 1988; 74: 392-397.

20. Hahn G, Stuhimuller B, Hain N, et al. Modulation of monocyte activation in patients with rheumatoid arthritis by leukapheresis therapy: J Clin Invest 1993; 91: 862-870.

21. Hrson DC, Sheldon J, Riches P, Hobbs JR. Cytokine induction of neopterin production. Clin Exp Immunol 1991; 30: 101-106.

22. Barak M, Gruener N. Neopterin augmentation of tumor necrosis factor production. Immunol Lett 1991; 30: 101-106.

23. Hoffmann G, Frede S, Kenn S, et al. Neopterin-induced tumor necrosis factor-a synthesis in vascular smooth muscle cells in vitro. Int Arch Allergy Immunol 1998; 116: $240-245$. 
24. Tan EN, Cohen AS, Fries JF, et al. The 1982 revised criteria for the classification of systemic lupus erythematosus. Arthritis Rheum 1982; 25: 1271.

25. Vitali C, Bencivelli W, Isenberd DA, et al. Disease activitv in systemic lupus erythematosus: report of the Consensus Study Group in the European Workshop for Rheumatology Research. II. Identification of the variables of discase activity and their use in the development of an activity score. Clin Exp Rheumatol 1992; 10: 541-547.

26. Arnrett FC, Edworth SM, Bloch DA, et al. The American Rhcumatism Association 1987 revised criteria for the classification of rheumatoid arthritis. Arthritis Rheum 1988; 31: 315-324.

27. Whiche WS, Sweeney TJ, Calabrese LH. Early, aggressive therapy for rheumatoid arthritis: concerns, descriptions, and estimate of outcome. Semin Arthritis Rheum 1993; 23: 26-41.

28. Bohan A, Peter JB. Polymyositis and dermatomyositis (first of two parts). N Engl J Med 1975; 292: 344-347.

29. Leavitt RY, Fauci AS, Bloch DA, et al. The American College of Rheumatology 1990 criteria for the classification of Wegeners granulomatosis. Arthritis Rheum 1990; 33: 1101-1107.

30. I uqmani RA, Bacon PA, Moots RJ, et al. Birmingham vasculitis activity score (BVAS) in systemic necrotizing vasculitis. Q J Med 1994; 87: 671-678.

31. Felson DT, Anderson JF, Boers M, et al. American College of Rheumatology preliminary definition of improvement in rheumatoid arthritis. Arthritis Rheum 1995; 38: $727-735$

32. Samsonov MY, Tilz GP, Egorova O, et al. Serum soluble markers of immunc activation and disease activity in systemic lupus erythematosus. Lupus 1994; 4: 29-32.

33. Snov M, Tilz GP, Pisklakov V, et al. Serum soluble receptors for tumor necrosis factor alpha and interlcukin-2, and neopterin in acute rheumatic fever. Clin Immunol Immunophatol 1995; 74: 31-34.

34. Samsonov MY, Nassonov EL, Tilz GP, et al. Elevated serum levels of neopterin in adult patients with polymyositis/dermatomyositis. Br J Rheumatol 1997; 36: 656-660.
35. Wollhcim FA. Established and new biochemical tools for diagnosis and monitoring of rheumatoid arthritis. Curr. Opin. Rheumatol. 1996; 8: 21-225.

36. Otterness IG. The value of C-reactive protein measurement in rheumatoid arthritis. Semin Arthritis Rheum 1994; 24: 91-104.

37. Reibnegger G, Egg D, Fuchs D, et al. Urinary neopterin reflects clinical activity in patients with rheumatoid arthritis. Arthritis Rheum. 1986; 29: 1063-1070.

38. Segal R, Bermas BL, Dayan M, et al. Kinetics of cytokine production in experimental systemic lupus erythematosus: involvement of $\mathrm{T}$ helper cell $1 / \mathrm{T}$ helper 2 trpe cytokine in disease. J Immunol 1997; 158: 300316.

39. Hohfeld R, Engel A. The immunobiology of muscle. Immunology Today 1994; 15: 269-273.

40. Kaliyapcrumal A, Mohan C, Wu W, Datta SK. Nucleosomal peptide epitopes for nephritis-inducing $\mathrm{T}$ helper cells of murine lupus. J Exp Med 1996; 183: 2459 2469.

41. Datta SK, Kalled SL. CD40-CD40 ligand interaction in autoimmune disease. Arthritis Rheum 1997; 40: $1735-1745$.

42. Jacob CO, van der Meilde PH, McDevitt HO. In vivo treatment of (NZBxNZW)Fl lupus-kike nephritis with monoclonal antibody to $\gamma$ interferon. J Exp Med 1987; 166: $978-803$.

43. Ozmen L, et al. Experimental therapy of systemic lupus erythematosus: the treatment of $\mathrm{NZB} / \mathrm{W}$ mice with mouse soluble interferon- $\gamma$ receptor inhibits the onset of glomerulonephritis. Eur J Immunol 1995; 25: 6-12.

44. Hooks JJ, Jordan GW, Cupps T, et al. Multiple interferons in the circulation of patients with systemic lupus ervthematosus. and vasculitis. Arthritis Rheum 1982; 25: 396-400.

45. Peng SL, Mosleshi J, Craft J. Roles of interferon-g and interleukin-4 in murine lupus. J Clin Invest 1997; 99 : 1936-1946.

46. Horwitz DA, Gray JD, Behrendsen SC, et al. Decreased production of interleukin- 12 and other ThI-type cytokines in patients with recent-onset systemic lupus erythematosus. Arthritis Rhcum 1998; 41: 838-844. 